\title{
Computer Simulation in Pharmacokinetic and Pharmacodynamic Studies
}

\author{
Durgawati Patel ${ }^{1}$ and Puspendra Kumar ${ }^{2 *}$ \\ ${ }^{1}$ Department of Chemistry, Banasthali University, India \\ ${ }^{2}$ KIET School of Pharmacy, KIET Group of Institutions, India
}

Submission: August 21, 2017; Published: September 22, 2017

*Corresponding author: Puspendra Kumar, KIET Group of Institutions, India, Email: puspendrapatel9@gmail.com

\begin{abstract}
Computer simulation in the field of Pharmacokinetic and Pharmacodynamics or in silica model is need of the hour in the biomedical field. In silica studies helps the research with ease and effectiveness. The current review summarises the various computer simulation models for different drugs with their outcomes. The current field is still under developed and needs more number of researches to achieve the goals.

Keywords: Computer simulation; Pharmacokinetic; Pharmacodynamics; Monte carlo simulation; In-silico studies
\end{abstract}

\section{Mini Review}

Current scenario is based on rapid development of technologies and computer simulation is an integral part in the field of pharmacokinetic and pharmacodynamics studies. It helps to rapid development of dosage forms with cheaper price and by using less manpower [1]. Medical field is still slow in accepting the computer simulation models. Simulation can play a major role for selection of studies to be performed; clinical trial simulation covers many disciplines i.e. pharmacokinetics, pre clinical pharmacologist, statistician, computer programmer etc. So, all experts can discuss and precede the appropriate research [2]. Understanding of the aim and objectives of the work is very essential for all experts and it's a tedious job; and the main reason behind the less development of the simulation technique in the field of medical field [3].

Computer simulation methods are based on availability of literature and studies regarding pharmacokinetic and pharmacodynamics parameters of the selected drugs [4]. Success of computer simulations methods are depended on quality of data inputs available [5]. Previous studies are taken as a reference to predict the simulation; and computer simulations demonstrate the pharmacokinetic parameters (i.e. half lives) of different drugs [6]. Computer simulations can give atomic details which are not accessible from experiments and help to elucidate the mechanism of the passive permeation process at a molecular level [7].

\section{Current Development in Computer Simulation}

All the medicines should undergo to a development and assessment processes before launching to the market. Safety of the patient is main concern for everyone especially in the case of drugs; so scrutiny and rigorous testing of the product before commercialization is highly essential. Some products fall into the potential harmful substances and repeated preclinical and clinical studies are harmful for animals and humans; so computer simulation can fill the gap and gives better result. Currently computer simulation models are promoted to overcome all these issues, but still this area is under developed and requires more development (Table 1) [8-10].

Table 1: Details do drugs investigated by various computer simulation models for pharmacokinetic and pharmacodynamic studies.

\begin{tabular}{|c|c|c|c|c|c|}
\hline S. No. & Drug Under Investigation & $\begin{array}{c}\text { Drug Under } \\
\text { Investigation }\end{array}$ & Simulator Details & Outcome & References \\
\hline 1. & $\begin{array}{c}\text { Fentanyl, alfentanil and } \\
\text { sufentanil }\end{array}$ & $\begin{array}{c}\text { Simulation of the } \\
\text { plasma and effect site } \\
\text { opioid concentrations } \\
\text { after bolus injection. }\end{array}$ & $\begin{array}{c}\text { 80386 computer running } \\
\text { MS-DOS (Microsoft, } \\
\text { Redmond, WA) using } \\
\text { program written in the C } \\
\text { language by Steven L. Shafer }\end{array}$ & $\begin{array}{c}\text { The simulation } \\
\text { predicts fentanyl, } \\
\text { alfentanil and } \\
\text { concentrations of 1.8, } \\
88 \text { and 0.99ng/ml } \\
\text { respectively. }\end{array}$ \\
\hline
\end{tabular}




\begin{tabular}{|c|c|c|c|c|c|}
\hline 2. & Paracetamo & $\begin{array}{l}\text { Pharmacokinetic and } \\
\text { dynamic model was } \\
\text { applied to predict } \\
\text { the dosing schedule } \\
\text { of paracetamol } \\
\text { to maintain the } \\
\text { steady state plasma } \\
\text { concentration. The } \\
\text { study is based on the } \\
\text { study of children aged } \\
1 \text { to } 17 \text { years. }\end{array}$ & $\begin{array}{l}\text { Computer modelling using } \\
\text { pharmacokinetic dynamic } \\
\text { simulation with MKMODEL } \\
\text { program. }\end{array}$ & $\begin{array}{l}70 \mathrm{mg} / \mathrm{kg} \text { loading } \\
\text { dose and } 50 \mathrm{mg} / \mathrm{kg} \\
\text { maintenance dose } \\
\text { was predicted by } \\
\text { simulation to achieve } \\
\text { the satisfactory } \\
\text { therapeutic effect. }\end{array}$ & {$[4]$} \\
\hline 3. & Corticosteroids & $\begin{array}{l}\text { Corticosteroid } \\
\text { pharmacokinetics in } \\
\text { the cochlear fluids for } \\
\text { inner ear disorders. }\end{array}$ & $\begin{array}{c}\text { Simulated with a finite } \\
\text { element computer model, } \\
\text { the Washington University } \\
\text { Cochlear Fluids Simulator, } \\
\text { version } 1.6\end{array}$ & $\begin{array}{c}\text { The application } \\
\text { protocol has a } \\
\text { significant effect } \\
\text { on the drug levels } \\
\text { achieved in per lymph, } \\
\text { with different delivery } \\
\text { strategies resulting } \\
\text { in very different } \\
\text { amounts of drugs in } \\
\text { the per lymph }\end{array}$ & {$[11]$} \\
\hline 4. & $\begin{array}{l}\text { Small molecules (Water, } \\
\text { acetamide, acetic acid, ethane, } \\
\text { methylamine, methanol, } \\
\text { methyl acetate, benzene) }\end{array}$ & $\begin{array}{l}\text { Understanding passive } \\
\text { membrane permeation } \\
\text { for rational drug } \\
\text { design }\end{array}$ & $\begin{array}{c}\text { Atomistic molecular } \\
\text { dynamics (MD) simulations } \\
\text { to calculate lipid membrane } \\
\text { permeability coefficients. } \\
\text { All of the simulations } \\
\text { were run in parallel with } 4 \\
\text { processors, using version } \\
27 \text { of the CHARMM software } \\
\text { package. }\end{array}$ & $\begin{array}{c}\text { Permeability } \\
\text { coefficients for } \\
\text { eight small organic } \\
\text { molecules have been } \\
\text { calculated by means } \\
\text { of MD simulations. } \\
\text { Solubility-diffusion } \\
\text { model as applied } \\
\text { in the context of } \\
\text { molecular dynamics } \\
\text { computer simulations } \\
\text { is able to reproduce } \\
\text { the relative } \\
\text { permeability's of eight } \\
\text { small molecule }\end{array}$ & {$[7]$} \\
\hline 5. & Meropenem & $\begin{array}{l}\text { Meropenem is } \\
\text { a carbapenem } \\
\text { antibiotic with a very } \\
\text { broad spectrum of } \\
\text { activity that makes } \\
\text { it a good choice } \\
\text { for the empirical } \\
\text { therapy situation. } \\
\text { Pharmacokinetic } \\
\text { calculations were } \\
\text { done by use of a two- } \\
\text { compartment open } \\
\text { model. The study was } \\
\text { done for two doses. }\end{array}$ & $\begin{array}{l}\text { Monte Carlo simulations for } \\
\text { 10,000 simulated subjects } \\
\text { for pharmacodynamic } \\
\text { evaluation }\end{array}$ & $\begin{array}{l}\text { high-dose continuous } \\
\text { infusion has a robust } \\
\text { probability of target } \\
\text { attainment up to } \\
\text { an MIC of } 4 \mathrm{mg} / \\
\text { litre. The lower-dose } \\
\text { probability of target } \\
\text { attainment is still } \\
\text { robust up to an MIC of } \\
2 \mathrm{mg} / \text { litre. }\end{array}$ & {$[12]$} \\
\hline 6. & $\begin{array}{l}\text { Farnesyl pyrophosphate } \\
\text { synthase (FPPS) }\end{array}$ & $\begin{array}{l}\text { FPPS is key cellular } \\
\text { intermediate in } \\
\text { isoprenoid metabolic } \\
\text { pathways. On the } \\
\text { basis of structural and } \\
\text { kinetic data, different } \\
\text { catalytic mechanisms } \\
\text { have been proposed } \\
\text { for FPPS. }\end{array}$ & $\begin{array}{l}\text { Computation simulations } \\
\text { were performed at the } \\
\text { density functional theory } \\
\text { (DFT) level with the SIESTA. }\end{array}$ & $\begin{array}{l}\text { Results are relevant } \\
\text { for the understanding } \\
\text { of this important class } \\
\text { of enzymes and for } \\
\text { the design of more } \\
\text { potent and specific } \\
\text { inhibitors for the } \\
\text { treatment of parasitic } \\
\text { diseases. }\end{array}$ & [13] \\
\hline 7. & CNS drug (R1315) & $\begin{array}{l}\text { Oral bioavailability } \\
\text { prediction was studied } \\
\text { as a function of the } \\
\text { particle size and drug } \\
\text { solubility. }\end{array}$ & $\begin{array}{l}\text { Computer simulations } \\
\text { were performed with the } \\
\text { software Gastro Plus TM } \\
\text { V.4.0 (Simulations Plus Inc., } \\
\text { Lancaster, USA), }\end{array}$ & $\begin{array}{l}\text { Simulation together } \\
\text { with the statistically } \\
\text { designed dog study } \\
\text { provided a thorough } \\
\text { biopharmaceutical } \\
\text { assessment of the new } \\
\text { CNS drug. }\end{array}$ & {$[5]$} \\
\hline
\end{tabular}




\begin{tabular}{|c|c|c|c|c|c|}
\hline 8. & $\begin{array}{l}\text { Lipophilic drugs (Danazol, } \\
\text { Dipyridamole, Efavirenz, } \\
\text { Exemestane, Gefitinib, } \\
\text { Griseofulvin, Ivermectin, } \\
\text { Ketoconazole, Ketoprofen, } \\
\text { Nitrendipine, Phenytoin, } \\
\text { Spironolactone) }\end{array}$ & $\begin{array}{l}\text { For the models of } \\
\text { poorly water-soluble } \\
\text { drugs, neutral, free } \\
\text { weak acid, and free } \\
\text { weak base drugs were } \\
\text { selected. }\end{array}$ & $\begin{array}{l}\text { Runge-Kutta method used } \\
\text { in STELLA 5.1.1 software } \\
\text { (Cognitus Ltd., North } \\
\text { Yorkshire, UK). }\end{array}$ & $\begin{array}{l}\text { The mini scale } \\
\text { dissolution test } \\
\text { integrated with a } \\
\text { computer simulation } \\
\text { system could simulate } \\
\text { quantitatively the in } \\
\text { vivo absorption of } \\
\text { structurally diverse } \\
\text { BCS class II drugs. }\end{array}$ & [14] \\
\hline 9. & Methylprednisolone & $\begin{array}{l}\text { Computer simulations } \\
\text { allow application } \\
\text { protocols and drug } \\
\text { delivery systems to } \\
\text { be evaluated, and may } \\
\text { permit animal studies } \\
\text { to be extrapolated to } \\
\text { the larger cochlea of } \\
\text { the human. }\end{array}$ & $\begin{array}{l}\text { 3D model was implemented } \\
\text { in a commercial software } \\
\text { package for finite-element } \\
\text { calculations (ANSYS } \AA \text {, } \\
\text { ANSYS Inc., Canonsburg Pa., } \\
\text { USA) }\end{array}$ & $\begin{array}{l}\text { 3D computations } \\
\text { demonstrate } \\
\text { the existence of } \\
\text { substantial gradients } \\
\text { across the scale in the } \\
\text { basal turn. }\end{array}$ & [15] \\
\hline 10. & Insulin & $\begin{array}{c}\text { subcutaneous (SC) } \\
\text { insulin absorption } \\
\text { model for computer } \\
\text { simulation in a clinical } \\
\text { diabetes }\end{array}$ & AIDA insulin PK model & $\begin{array}{l}\text { Ability of the } \\
\text { model to capture } \\
\text { the fundamental } \\
\text { dynamics of insulin } \\
\text { action for several } \\
\text { insulin types based } \\
\text { on data from a wide } \\
\text { range of studies using } \\
\text { a unified consistent } \\
\text { PK model. }\end{array}$ & [16] \\
\hline 11. & Erlotinib & $\begin{array}{l}\text { Selected model } \\
\text { predicted that CYP3A4 } \\
\text { contributed to } \sim 70 \% \\
\text { of the metabolic } \\
\text { elimination of } \\
\text { erlotinib, with CYP1A2 } \\
\text { being responsible for } \\
\text { the other } \sim 30 \% \text {. A } \\
\text { drug-drug interaction } \\
\text { study was therefore } \\
\text { conducted for erlotinib }\end{array}$ & Simulation model, SimCYP ${ }^{\mathrm{TM}}$ & $\begin{array}{l}\text { Prediction of clinically } \\
\text { important drug-drug } \\
\text { interaction with } \\
\text { SimCYP }{ }^{\mathrm{TM}} \text { using in vitro } \\
\text { human metabolism } \\
\text { data can be a powerful } \\
\text { tool during early } \\
\text { clinical development }\end{array}$ & {$[17]$} \\
\hline 12. & $\begin{array}{l}\text { Doxorubicin } \\
\text { and cisplatin }\end{array}$ & $\begin{array}{l}\text { Investigation of the } \\
\text { pharmacokinetics } \\
\text { and effect of } \\
\text { selected drugs in } \\
\text { vascularised tumours } \\
\text { by two-dimensional } \\
\text { simulations. }\end{array}$ & $\begin{array}{l}\text { Computer (in silico) } \\
\text { simulations based on } \\
\text { mathematical modelling } \\
\text { and calibrated with } \\
\text { experimental data }\end{array}$ & $\begin{array}{l}\text { Computational models } \\
\text { have the potential } \\
\text { to facilitate an era } \\
\text { of great discovery } \\
\text { and progress in } \\
\text { understanding and } \\
\text { treating cancer }\end{array}$ & [18] \\
\hline 13. & $\begin{array}{l}\text { BCS class I drugs (propranolol } \\
\text { and metoprolol) and BCS class } \\
\text { III drugs (cimetidine, atenolol, } \\
\text { and amoxicillin) }\end{array}$ & $\begin{array}{c}\text { In silico } \\
\text { bioequivalence studies } \\
\text { to assess the feasibility } \\
\text { of extending bio } \\
\text { waivers to BCS class } \\
\text { III drugs }\end{array}$ & $\begin{array}{l}\text { Simulation was done by } \\
\text { Gastro Plus (version } 6.0 \text { ) }\end{array}$ & $\begin{array}{l}\text { The results of Gastro } \\
\text { Plus simulations } \\
\text { indicate that the } \\
\text { dissolution rate of BCS } \\
\text { class III drugs could } \\
\text { be prolonged, rather } \\
\text { than permeability. }\end{array}$ & [19] \\
\hline 14. & $\begin{array}{l}\text { carbamazepine (CBZ) and } \\
\text { its main active metabolite } \\
\text { carbamazepine-10,11- } \\
\text { epoxide (CBZE) }\end{array}$ & $\begin{array}{l}\text { CBZ and CBZE time- } \\
\text { concentration profiles } \\
\text { in various scenarios } \\
\text { were generated based } \\
\text { on a population } \\
\text { pharmacokinetic study } \\
\text { using Monte Carlo } \\
\text { simulation }\end{array}$ & $\begin{array}{l}\text { Monte Carlo simulations } \\
\text { with \$SIMULATION } \\
\text { block in the NONMEM } \\
\text { software (Version 7.2; } \\
\text { Icon Inc, PA, USA) with the } \\
\text { ONLYSIM-ULATION and } \\
\text { SUBPROBLEMS option }\end{array}$ & $\begin{array}{l}\text { The risk for a sub- } \\
\text { therapeutic range of } \\
\text { CBZ and CBZE was } \\
\text { increased in a dose- } \\
\text { dependent manner }\end{array}$ & [20] \\
\hline
\end{tabular}




\section{Conclusion}

More number of research and experts are required in the field of in silico computer simulation field to improve the product trials and replacement of animals and human during clinical trials. Subject specific model studies are recommended in which living models can be easily replaced by in silico models. The major challenge in the field of in silico pharmacokinetic and Pharmacodynamic studies is the harmony of understanding between the pharmacokinetics and computer programmer.

\section{References}

1. Bonate PL (2000) Clinical trial simulation in drug development Pharmaceutical research 17(3): 252-256.

2. Bonate PL (2001) A brief introduction to Monte Carlo simulation. Clinical pharmacokinetics 40(1): 15-22.

3. Johnson SC (1998) The role of simulation in the management of research: what can the pharmaceutical industry learn from the aerospace industry? Therapeutic Innovation \& Regulatory Science.

4. Anderson B, Holford N (1997) Rectal paracetamol dosing regimens: determination by computer simulation. Pediatric Anesthesia 7(6): 451-455.

5. Kuentz M, Nick S, Parrott N, Röthlisberger D (2006) A strategy for preclinical formulation development using GastroPlus ${ }^{\mathrm{TM}}$ as pharmacokinetic simulation tool and a statistical screening design applied to a dog study. European journal of pharmaceutical sciences 27(1): 91-99.

6. Shafer SL, Varvel JR (1991) Pharmacokinetics, pharmacodynamics, and rational opioid selection. Anesthesiology 74(1): 53-63.

7. Bemporad D, Essex JW, Luttmann C (2004) Permeation of small molecules through a lipid bilayer: a computer simulation study. The Journal of Physical Chemistry B 108(15): 4875-4884.

8. Viceconti M, Henney A, Morley-Fletcher E (2016) In silico clinical trials: how computer simulation will transform the biomedical industry. International Journal of Clinical Trials 3(2): 37-46.

9. Fuchs A, Csajka C, homa Y, Buclin T, Widmer N (2013) Benchmarking therapeutic drug monitoring software: a review of available computer tools. Clinical pharmacokinetics 52(1): 9-22.

10. Chabaud S, Girard P, Nony P, Boissel JP (2002) Clinical trial simulation using therapeutic effect modeling: application to ivabradine efficacy

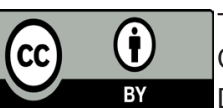

This work is licensed under Creative

Commons Attribution 4.0 Licens

DOI: 10.19080/MABB.2017.02.555582 in patients with angina pectoris. Journal of pharmacokinetics and pharmacodynamics 29(4): 339-363.

11. Plontke SK, Salt AN (2003) Quantitative interpretation of corticosteroid pharmacokinetics in inner fluids using computer simulations. Hearing research 182(1-2): 34-42.

12. Krueger WA, Bulitta J, Kinzig-Schippers M, Landersdorfer C, Holzgrabe U, et al. (2005) Evaluation by Monte Carlo simulation of the pharmacokinetics of two doses of meropenem administered intermittently or as a continuous infusion in healthy volunteers. Antimicrobial agents and chemotherapy 49(5): 1881-1889.

13. Sanchez VM, Crespo A, Gutkind JS, Turjanski AG (2006) Investigation of the catalytic mechanism of farnesyl pyrophosphate synthase by computer simulation. The Journal of Physical Chemistry B 110(36): 18052-18057.

14. Takano R, Sugano K, Higashida A, Hayashi Y, Machida M, et al. (2006) Oral absorption of poorly water-soluble drugs: computer simulation of fraction absorbed in humans from a mini scale dissolution test. Pharmaceutical research 23(6): 1144-1156.

15. Plontke SK, Siedow N, Wegener R, Zenner HP, Salt AN (2007) Cochlear pharmacokinetics with local inner ear drug delivery using a three-dimensional finite-element computer model. Audiology and Neurotology 12(1): 37-48.

16. Wong J, Chase JG, Hann CE, Shaw GM, Lotz TF, et al. (2008) A subcutaneous insulin pharmacokinetic model for computer simulation in a diabetes decision support role: validation and simulation. Journal of diabetes science and technology 2(4): 672-680.

17. Rakhit A, Pantze MP, Fettner, Jones HM, Charoin JE, et al. (2008) The effects of CYP3A4 inhibition on erlotinib pharmacokinetics: computerbased simulation (SimCYP) predicts in vivo metabolic inhibition European journal of clinical pharmacology 64(1): 31-41.

18. Sinek JP, Sanga S, Zheng X, Frieboes HB, Ferrari M, et al. (2009) Predicting drug pharmacokinetics and effect in vascular zed tumors using computer simulation. Journal of mathematical biology 58(4-5): 485-510.

19. Tsume Y, Amidon GL (2010) The biowaiver extension for BCS class III drugs: the effect of dissolution rate on the bioequivalence of BCS class III immediate-release drugs predicted by computer simulation. Molecular pharmaceutics 7(4): 1235-1243.

20. Ding JJ, Zhang YJ, Jiao Z, Wang Y (2012) The effect of poor compliance on the pharmacokinetics of carbamazepine and its epoxide metabolite using Monte Carlo simulation. Acta Pharmacological Sinica 33(11): $1431-1440$

\section{Your next submission with Juniper Publishers will reach you the below assets}

- Quality Editorial service

- Swift Peer Review

- Reprints availability

- E-prints Service

- Manuscript Podcast for convenient understanding

- Global attainment for your research

- Manuscript accessibility in different formats

( Pdf, E-pub, Full Text, Audio)

- Unceasing customer service

Track the below URL for one-step submission https://juniperpublishers.com/online-submission.php 